\title{
Keanekaragaman Serangga Fitofag pada Sengon Falcataria moluccana (Miq.) Barneby \& J. W. Grimes dari Jawa dan Hawaii di Persemaian di Bogor
}

\section{(The Diversity of Phytophagous Insects on Albizia Falcataria moluccana (Miq.) Barneby \& J. W. Grimes from Java and Hawaii in Seedling in Bogor)}

\author{
Yendra Pratama Setyawan ${ }^{1 *}$, Purnama Hidayat ${ }^{2}$, Hermanu Triwidodo $^{2}$, Kenneth Puliafico $^{3}$
}

(Diterima Februari 2021/Disetujui Mei 2021)

\begin{abstract}
ABSTRAK
Sengon (Falcataria moluccana) banyak dibudidayakan di Indonesia karena memiliki nilai ekonomi yang tinggi, akan tetapi sengon juga dikategorikan sebagai invasive alien species, khususnya di Kepulauan Hawaii yang mengakibatkan kerugian ekonomi maupun ekologi. Pengendalian tumbuhan invasif yang berbasis pengendalian hayati merupakan metode yang efektif. Tujuan penelitian ini adalah untuk mengeksplorasi serangga fitofag pada pembibitan sengon yang berasal dari Jawa dan Hawaii. Penelitian ini dilaksanakan di Desa Carangpulang, Kecamatan Dramaga, Bogor. Desain percobaan menggunakan rancangan acak kelompok lengkap dengan asal tanaman sebagai perlakuan (sengon dari Jawa dan Hawaii) serta 4 ulangan. Total tanaman sampel adalah 160 tanaman. Pengamatan serangga dilakukan setiap 2 minggu hingga tanaman umur 32 minggu setelah tanam. Identifikasi serangga dilakukan di Laboratorium Biosistematika Serangga IPB. Hasil pengamatan menunjukkan 67 spesies serangga fitofag berasosiasi dengan sengon. Sebanyak 57 spesies berasosiasi dengan sengon dari Jawa dan 54 spesies berasosiasi dengan sengon dari Hawaii. Tidak terdapat perbedaan kelimpahan dan keanekaragaman serangga fitofag yang berasosiasi dengan sengon di kedua lokasi tersebut. Larva Eurema blanda (Lepidoptera: Pieridae) menjadi hama penting pada persemaian sengon yang mengakibatkan defoliasi. Beberapa serangga seperti Hulodes caranea (Lepidoptera: Noctuidae), Margarodes sp. (Hemiptera: Margarodidae), Choristoneura sp. (Lepidoptera: Tortricidae), serta Adoxophyes sp (Lepidoptera: Tortricidae) merupakan hama pada persemaian sengon yang belum dilaporkan sebelumnya.
\end{abstract}

Kata kunci: Fabaceae, hama penting, sengon, serangga defoliator, tanaman invasive

\section{ABTRACT}

Albizia (Falcataria moluccana) cultivated in Indonesia for timber plantations can increase the farmer's income, even though albizia became an invasive alien species that can cause the economic and ecological losses. The controlling of invasive species using biological control is an effective method. The purpose of this study was to determine the phytophagous insects on albizia from Java and Hawaii in seedling in Bogor. The experiment was conducted in Carangpulang, Dramaga, Bogor. The experiment was arranged in a completely randomized block design using seed origin as a treatment (albizia Java and Hawaii) with 4 replicates. Total number of tree sample was 160 trees. Observations were conducted every 2 weeks until 32 weeks after planting. Identification of insects was conducted in the Laboratory of Insect Biosystematics, IPB. A total of 67 phytophagous insects were collected, 57 species in albizia from Java and 54 species in albizia from Hawaii. There was no difference in abundance and diversity of phytophagous insects on albizia from Java and Hawaii. Larvae of Eurema blanda (Lepidoptera: Pieridae) became an important pest causes leaf defoliation. Furthermore, Hulodes caranea (Lepidoptera: Noctuidae), Margarodes sp. (Hemiptera: Margarodidae), Choristoneura sp. (Lepidoptera: Tortricidae), and Adoxophyes sp. (Lepidoptera: Tortricidae) identified as important pests that have not been reported in the other research.

Keywords: albizia, defoliator insect, Fabaceae, important pests, invasive alien species

1 Pest \& Entomology Section, Crop Protection Department, SMART Research Institute, Jl. Teuku Umar 19, Pekanbaru, Riau 28112 Indonesia

2 Departemen Proteksi Tanaman, Fakultas Pertanian, Institut Pertanian Bogor, JI. Meranti, Kampus IPB Darmaga, Bogor 16680 Indonesia

3 USDA Forest Service, Institute of Pasific Islands Foresty, 60 Nowelo St, Hilo HI, 96720 USA

* Penulis Korespondensi:

E-mail: yendrapratama2@gmail.com

\section{PENDAHULUAN}

Falcataria moluccana termasuk famili Fabaceae dan lebih dikenal dengan nama sengon merupakan tanaman asli Indonesia (Maluku), Papua New Guinea, dan Kepulauan Solomon (Nair 2007). Tanaman ini dapat ditemukan di beberapa negara di kawasan Asia Tenggara serta banyak dibudidayakan karena memiliki nilai ekonomi yang tinggi (Siregar et al. 2007; Surachman et al. 2014). Sengon juga dilaporkan 
terdapat di beberapa pulau kecil di kawasan Samudra Pasifik, seperti di Kepulauan Hawaii (Starr et al. 2003; Haines et al. 2011; Krisnawati et al. 2011).

Sengon pada awalnya dimanfaatkan untuk keperluan reboisasi di kawasan hutan Kepulauan Hawaii sejak tahun 1917 yang dibawa dari Jawa dan Kalimantan karena tergolong fast growing species (Murdiyarso et al. 1992; Starr et al. 2003; Hughes et al. 2013). Reboisasi tersebut telah berhasil sehingga persebaran sengon merata di seluruh Kepulauan Hawaii (Hughes et al. 2013). Keberhasilan persebaran tersebut menyebabkan sengon dikategorikan sebagai salah satu tanaman asing (exotic plants) yang mampu menginvasi berbagai lokasi kawasan hutan hingga taman kota di Hawaii (Starr et al. 2003; BIISC 2015). Kemampuan menginvasi ini juga dapat menimbulkan dampak negatif, seperti kerugian ekonomi, biodiversitas lokal, dan ekologi (Richardson et al. 2000; Vila et al. 2011; Wong 2012; Chandler et al. 2016). Dampak ekologi antara lain memengaruhi ekosistem perairan di daerah tepi sungai dan memicu invasi gulma, seperti Psidium cattleianum (Hughes et al. 2013).

Keberhasilan pertumbuhan tumbuhan asing di tempat barunya terjadi akibat perubahan pola alokasi biomassa dan seleksi genotipe yang mendukung pertumbuhan (Cappuccino \& Carpenter 2005; Zou et al. 2008a). Perubahan tersebut mengakibatkan peningkatan kemampuan kompetitif dengan peningkatan pertumbuhan vegetatif tanaman (Lieurance 2012). Hal tersebut sesuai dengan hipotesis Blossey dan Notzold (1995) dan didukung oleh Frenzel dan Brandl (2003) yang menyatakan bahwa tumbuhan pendatang mampu meningkatkan resistansinya terhadap serangga herbivora dan meningkatkan pertumbuhan atau reproduksinya karena jarang diserang oleh herbivora.

Sejauh ini, pengendalian dilakukan dengan cara mekanik dan kimia untuk menekan persebaran sengon di Kawasan Hawaii (Hughes et al. 2013; Chandler et al. 2016). Pengendalian hayati diperlukan untuk mengendalikan persebaran populasi dan melindungi biodiversitas hayati asli kepulauan tersebut (Kolar \& Lodge 2001; Blumenthal 2005). Eksplorasi serangga fitofag dari daerah asal introduksi diperlukan untuk mendapatkan musuh alami yang sesuai, terutama pada fase sebelum tumbuhan tersebut tumbuh besar dan mengakibatkan kerugian lebih lanjut (BIISC 2015). Penelitian serangga fitofag yang berasosiasi dengan sengon pada tahap persemaian merupakan salah satu upaya yang dapat digunakan untuk mengetahui jenis serangga fitofag yang dapat mengakibatkan kerusakan pada fase awal pertumbuhan.

Pendekatan yang dilakukan untuk mengetahui perbedaan serangga fitofag yang berasal dari kedua daerah yang berbeda, yaitu digunakan sengon dari daerah Jawa (asal introduksi) (Starr et al. 2003; Hughes et al. 2013) dan tanaman sengon yang diambil dari daerah Hawaii (tujuan introduksi). Penelitian ini sangat penting dilakukan untuk mengidentifikasi respons serangga fitofag terhadap kedua sengon dari asal yang berbeda dengan menggunakan percobaan kebun (garden experiment) (Joshi \& Vrieling 2005; Zou et al. 2008b). Lebih lanjut lagi, penelitian mengenai inventarisasi serangga fitofag pada sengon yang ditumbuhkan dari benih asal Jawa dan Hawaii juga belum pernah dilaporkan sebelumnya. Berdasarkan hal tersebut maka tujuan penelitian ini adalah untuk mengetahui jenis serangga fitofag yang menyerang tanaman muda (persemaian) sengon yang berasal dari Jawa dan Hawaii serta menentukan serangga fitofag yang menjadi hama penting pada persemaian sengon.

\section{METODE PENELITIAN}

\section{Waktu dan Tempat Penelitian}

Penelitian dilaksanakan pada bulan Juni 2016 hingga Juli 2017 di rumah kaca Cikabayan dan lahan percobaan Departemen Proteksi Tanaman di Desa Carangpulang, Dramaga, Bogor. Identifikasi serangga dilakukan di Laboratorium Biosistematika Serangga, Departemen Proteksi Tanaman, Fakultas Pertanian, Institut Pertanian Bogor.

\section{Rancangan Percobaan}

Rancangan percobaan yang digunakan adalah rancangan acak kelompok lengkap dengan 4 ulangan (blok), pengacakan menggunakan program Edgar II Randomization (Kleunen et al. 2010). Perlakuan yang digunakan adalah asal tanaman sengon dari Jawa dan sengon dari Hawaii. Jumlah tanaman sampel adalah 80 untuk setiap perlakuan sehingga total tanaman adalah 160 tanaman. Benih sengon dari Jawa didapatkan dari petani sengon Leuwisadeng, Kabupaten Bogor, sedangkan benih sengon dari Hawaii didapatkan dari Taman Nasional Hawaii Volcanoes.

\section{Penyemaian dan Pemindahan Sengon ke Lapangan}

Benih terlebih dahulu direndam di dalam larutan klorin $10 \%$ selama 10 menit. Setelah itu benih direndam kembali ke dalam air selama 24 jam. Selanjutnya benih disemai pada media tanah, kompos, dan sekam bakar (1:2:2) yang sudah disterilkan (Nusantara 2002; Soeparno \& Dwiyono 2013). Penyapihan dilakukan pada tanaman berumur 4 minggu setelah tanam (MST) dengan memindahkan bibit ke polibag berukuran $20 \mathrm{~cm}$ x $20 \mathrm{~cm}$. Media tanam yang digunakan adalah tanah, kompos, dan sekam bakar (5:3:2) (Budiawan et al. 2012). Polibag yang telah berisi bibit kemudian diletakkan di dalam rumah kaca.

Sengon yang sudah berumur 12 MST dipindahkan ke dalam polibag berukuran $40 \mathrm{~cm} \times 40 \mathrm{~cm}$ (Nusantara 2002). Lahan percobaan berada di lahan tanam Desa Carangpulang, Dramaga, Bogor. Lahan percobaan berukuran $86 \mathrm{~m} \times 8 \mathrm{~m}$. Terdapat 4 blok di dalam lahan, masing-masing blok berukuran $10 \mathrm{~m}$ x $8 \mathrm{~m}$ (antar blok berjarak $8 \mathrm{~m}$ ). Jumlah tanaman sampel setiap blok adalah 20 tanaman untuk setiap asal sengon (total sengon per blok adalah 40 tanaman). Penyusunan tanaman sampel setiap perlakuan terdiri atas 2 baris 
(antarbaris berjarak $2 \mathrm{~m}$ ). Pada setiap baris tanaman terdiri atas 10 tanaman (antartanaman berjarak 0,75 $\mathrm{m})$. Selanjutnya untuk perawatan di lapangan dilakukan penyiraman setiap 3 hari sekali apabila tidak ada hujan. Tidak ada penambahan kompos maupun pupuk yang digunakan selama di lapangan, hanya penyiangan rumput yang berada di dalam polibag dan tanah di sekitar polibag ( $\pm 30 \mathrm{~cm}$ dari polibag).

\section{Pengamatan dan Identifikasi Serangga Fitofag}

Pengamatan dilakukan secara berkala, yakni dengan interval 2 minggu sekali pada umur tanaman 14 MST sampai 32 MST. Pada setiap rotasi pengamatan dilakukan sensus serangga pada pagi hari (08.00 sampai 12.00 WIB). Pengamatan serangga fitofag dilakukan dengan pengamatan langsung pada seluruh bagian tanaman sampel, yaitu bagian pangkal batang yang berdekatan dengan permukaan tanah, batang, ranting, dan daun. Pengambilan sampel serangga dilakukan dengan pengambilan langsung dan insect net. Pengamatan dimulai dari baris selatan hingga baris utara. Sampel serangga yang terkoleksi kemudian dimasukkan ke dalam botol sampel berukuran $50 \mathrm{~mL}$ yang di dalamnya terdapat alkohol $70 \%$ selanjutnya dibawa ke laboratorium untuk identifikasi lebih lanjut.

Serangga pradewasa, seperti ulat dan nimfa, dipelihara hingga imago. Beberapa sampel yang telah didapatkan kemudian dibuat awetan basah dan kering. Jenis kutu-kutuan dibuat preparat slide yang selanjutnya diidentifikasi. Identifikasi serangga dilakukan dengan pengamatan karakter morfologi hingga tingkat spesies. Referensi yang digunakan mengacu pada kunci identifikasi dikotomi Immature Insect (Stehr 1987) maupun multiakses Leplntercept - An identification resource for intercepted Lepidoptera larvae (Gilligan \& Passoa 2014).

\section{Analisis Data}

Data hasil identifikasi kemudian ditabulasi menggunakan aplikasi Microsoft Office Excel 2016. Pengaruh perlakuan asal tanaman dianalisis dengan ANOVA menggunakan aplikasi SAS 9.4. Perhitungan keanekaragaman serangga dilakukan dengan menggunakan indeks keanekaragaman Shannon Wiener. Lebih lanjut lagi, untuk mengetahui spesies yang memiliki kontribusi dalam penyusunan komposisi spesies dilakukan uji Simper. Perbedaan komposisi spesies serangga fitofag dibandingkan dengan analisis kesamaan (ANOSIM) berdasarkan indeks kesamaan Bray-Curtis yang dituangkan dalam pola ordinasi multidimensional scaling (MDS) menggunakan program PAST 2.17.

\section{HASIL DAN PEMBAHASAN}

\section{Keanekaragaman Serangga Fitofag pada Sengon dari Jawa dan Hawaii}

Total serangga fitofag yang diidentifikasi berasosiasi dengan tanaman sengon hingga umur 32 MST adalah sebanyak 2718 individu, yang terdiri atas 4 ordo (ordo Coleoptera, Hemiptera, Lepidoptera, dan Orthoptera), 30 famili, dan 67 spesies (Tabel 1). Jumlah spesies yang ditemukan di sengon yang berasal dari Jawa adalah sebanyak 57 spesies dengan kelimpahan total 1694 individu, sedangkan pada sengon yang berasal dari Hawaii didapatkan fitofag sebanyak 54 spesies dengan kelimpahan total 1.024 individu.

Hasil dari perhitungan indeks keanekaragaman Shannon Wiener menunjukkan bahwa indeks keanekaragaman $\left(H^{\prime}\right)$ pada sengon Jawa $\left(H^{\prime}=1,557\right)$ dan sengon Hawaii $\left(H^{\prime}=1,656\right)$ menunjukkan nilai yang tidak jauh berbeda. Indeks keanekaragaman biasanya berkisar di antara 1 sampai 3,5 dan semakin tinggi nilai $\mathrm{H}^{\prime}$ semakin tinggi pula keanekaragaman spesiesnya (Stork 1988). Nilai indeks keanekaragaman yang tidak jauh berbeda menandakan bahwa keanekaragaman spesies pada sengon dari Jawa dan Hawaii juga tidak jauh berbeda.

Kedua sengon dari asal yang berbeda tersebut menunjukkan nilai keanekaragaman yang hampir sama dan tergolong tingkat keanekaragaman yang sedang. Keanekaragaman serangga fitofag yang berasosiasi dengan tanaman merupakan proses interaksi yang sangat kompleks, tidak hanya satu faktor saja berpengaruh di dalamnya tapi juga faktor-faktor lain yang saling berinteraksi (Stam et al. 2014). Keanekaragaman serangga fitofag yang memanfaatkan tanaman inangnya erat kaitannya dengan faktor lingkungan dan kondisi vegetasi sekitar (Tscharntke et al. 2016; Rizali et al. 2017).

Analisis ANOVA pada pengaruh perlakuan asal tanaman pada keanekaragaman jenis dan kelimpahan individu serangga fitofag (Gambar 1) menunjukkan hasil yang sama. Keanekaragaman jenis serangga fitofag tidak dipengaruhi oleh asal sengon (Gambar 1A; $p$ value $=0,0861$ ), begitu juga dengan kelimpahan individu serangga fitofag yang tidak dipengaruhi oleh asal sengon (Gambar 1B; $p$ value $=0,2415$ ). Meskipun nilai rata-rata keanekaragaman dan kelimpahan serangga fitofag pada sengon dari Jawa cenderung menunjukkan nilai rata-rata yang lebih tinggi dari pada sengon dari Hawaii, keduanya masih dalam taraf yang sama.

Tidak adanya pengaruh asal tanaman pada keanekaragaman dan kelimpahan serangga pada sengon Jawa dan Hawaii dimungkinkan karena struktur morfologi, nutrisi tanaman, serta senyawa volatil dari keduanya juga sama (Speight et al. 1999; Wikstrom et al. 2006; White et al. 2008). Hasil yang sama juga dijelaskan oleh Liu et al. (2006) dalam penelitiannya bahwa spesies Eugenia spp. yang telah diintroduksikan memiliki kekayaan serangga fitofag yang sama dengan Eugenia spp. dari tempat aslinya. Bürki dan Nentwig (1997) juga menjelaskan bahwa 
Tabel 1 Keanekaragaman serangga fitofag yang berasosiasi pada sengon dari Jawa dan Hawaii

\begin{tabular}{|c|c|c|c|c|c|}
\hline \multirow{2}{*}{ Ordo } & \multirow{2}{*}{ Famili } & \multirow{2}{*}{ Spesies } & \multirow{2}{*}{$\begin{array}{c}\text { Bagian } \\
\text { tanaman }\end{array}$} & \multicolumn{2}{|c|}{ Kelimpahan individu } \\
\hline & & & & Jawa & Hawaii \\
\hline \multirow[t]{10}{*}{ Coleoptera } & Chrysomelidae & Arthrotus histrio & Daun & 2 & 2 \\
\hline & & Diapromorpha pinguis & Daun & 2 & 1 \\
\hline & & Gastrophysa viridula & Daun & 2 & 0 \\
\hline & & Podontia affinis & Daun & 0 & 1 \\
\hline & Coccinellidae & Bucolus fourneti & Daun & 1 & 1 \\
\hline & Curculionidae & Dyscheres curtis & Daun & 10 & 9 \\
\hline & & Polydrusus formosus & Daun & 7 & 3 \\
\hline & Elateridae & Melanotus rufipes & Ranting & 2 & 3 \\
\hline & Lycidae & Metriorhynchus sp. & Daun & 3 & 4 \\
\hline & Scarabaeidae & Phyllophaga rugans & Batang & 1 & 0 \\
\hline \multirow[t]{18}{*}{ Hemiptera } & Alydidae & Homoeocerus marginellus & Daun & 2 & 0 \\
\hline & & Leptocorisa acuta & Daun & 17 & 29 \\
\hline & & Leptocorisa oratorius & Daun & 2 & 1 \\
\hline & & Riptortus linearis & Daun & 8 & 8 \\
\hline & Coccidae & Parthenolecanium corni & Ranting & 10 & 21 \\
\hline & Coreidae & Amblypelta lutescens & Daun & 3 & 1 \\
\hline & & Cletus trigonus & Daun & 1 & 2 \\
\hline & & Physomerus grossipes & Daun & 0 & 2 \\
\hline & Flatidae & Siphanta patruelis & Batang & 4 & 4 \\
\hline & Margarodidae & Margarodes sp. & Ranting & 24 & 16 \\
\hline & Membracidae & Anchon ulriforme & Daun & 1 & 0 \\
\hline & & Gargara genistae & Daun & 21 & 8 \\
\hline & & Leptocentrus taurus & Daun & 5 & 6 \\
\hline & & Membracidae sp. & Daun & 1 & 1 \\
\hline & Pseudococcidae & Ferrisia virgata & Ranting & 25 & 22 \\
\hline & Psyllidae & Acizzia uncatoides & Daun & 7 & 0 \\
\hline & Pyrrhocoridae & Dysdercus cingulatus & Daun & 0 & 1 \\
\hline & Ricaniidae & Ricania marginalis & Batang & 4 & 4 \\
\hline \multirow[t]{32}{*}{ Lepidoptera } & Amatiidae & Amata perixanthia & Daun & 0 & 1 \\
\hline & Cosmopterigidae & Macrobathra anacampta & Daun & 2 & 0 \\
\hline & & Morphotica mirifica & Daun & 1 & 1 \\
\hline & Erebidae & Orgyia detrita & Daun & 0 & 1 \\
\hline & & Orgyia postica & Daun & 4 & 1 \\
\hline & Geometridae & Besma quercivoraria & Daun & 0 & 2 \\
\hline & & Ennominae sp. & Daun & 0 & 1 \\
\hline & & Erannini sp. & Daun & 1 & 0 \\
\hline & & Geometridae sp. 10 & Daun & 1 & 0 \\
\hline & & Geometridae sp. 12 & Daun & 4 & 1 \\
\hline & & Geometrinae sp. 1 & Daun & 5 & 5 \\
\hline & & Hyposidra talaca & Daun & 4 & 3 \\
\hline & & Traminda mundissima & Daun & 3 & 1 \\
\hline & & Traminda prasodes & Daun & 7 & 2 \\
\hline & Limacodidae & Limacodinae sp. & Daun & 1 & 2 \\
\hline & Lycaenidae & Amblypodia narada & Daun & 1 & 0 \\
\hline & & Quercusia quercus & Daun & 7 & 7 \\
\hline & Noctuidae & Hulodes caranea & Daun & 22 & 22 \\
\hline & & Spodoptera litura & Daun & 1 & 0 \\
\hline & Notodontidae & Stauropus sp. & Daun & 0 & 1 \\
\hline & Nymphalidae & Doleschallia bisaltide & Daun & 1 & 0 \\
\hline & & Nymphalidae sp. & Daun & 1 & 0 \\
\hline & & Polyura hebe & Daun & 4 & 3 \\
\hline & Pieridae & Eurema blanda & Daun & 1253 & 592 \\
\hline & & Eurema hecabe & Daun & 61 & 22 \\
\hline & Psychidae & Psychidae sp. 2 & Daun & 0 & 2 \\
\hline & & Psychidae sp. 3 & Daun & 2 & 1 \\
\hline & & Psychidae sp. 4 & Daun & 4 & 5 \\
\hline & & Psychidae sp. 5 & Daun & 1 & 0 \\
\hline & & Psychidae sp. 6 & Daun & 0 & 2 \\
\hline & & Pteroma plagiophleps & Daun & 35 & 43 \\
\hline & Pyralidae & Ephestia kuehniella & Daun & 6 & 3 \\
\hline
\end{tabular}




\begin{tabular}{|c|c|c|c|c|c|}
\hline \multirow{2}{*}{ Ordo } & \multirow{2}{*}{ Famili } & \multirow{2}{*}{ Spesies } & \multirow{2}{*}{$\begin{array}{c}\text { Bagian } \\
\text { tanaman }\end{array}$} & \multicolumn{2}{|c|}{ Kelimpahan individu } \\
\hline & & & & Jawa & Hawaii \\
\hline \multirow{7}{*}{ Orthoptera } & Tortricidae & Adoxophyes sp. & Daun & 12 & 3 \\
\hline & & Choristoneura sp. & Daun & 26 & 14 \\
\hline & Acrididae & Oxya japonica & Daun & 1 & 1 \\
\hline & & Phlaeoba infumata & Daun & 7 & 7 \\
\hline & & Schistocerca nitens & Daun & 2 & 3 \\
\hline & & Schistocerca pallens & Daun & 33 & 111 \\
\hline & & Trilophidia annulata & Daun & 16 & 11 \\
\hline \multicolumn{4}{|c|}{ Jumlah spesies serangga fitofag } & 57 & 54 \\
\hline \multicolumn{4}{|c|}{ Total kelimpahan individu } & 1.694 & 1.024 \\
\hline \multicolumn{4}{|c|}{ Indeks keanekaragaman Shannon Wiener $\left(\mathrm{H}^{\prime}\right)$} & 1,557 & 1,656 \\
\hline
\end{tabular}
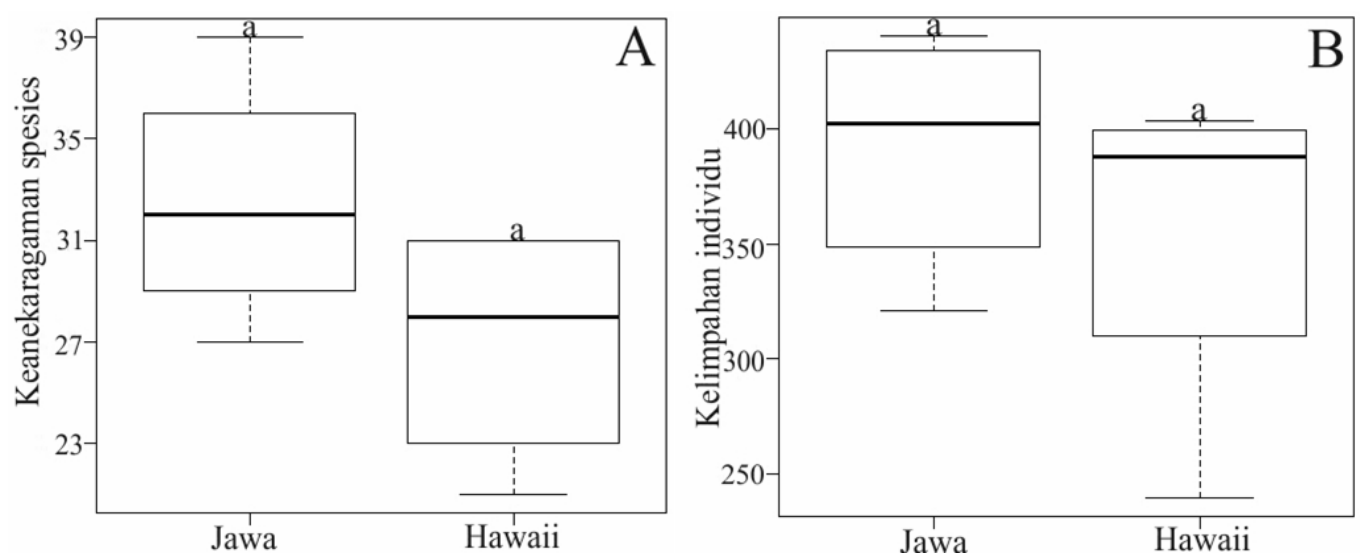

Gambar 1 Perbedaan keanekaragaman spesies (A) dan kelimpahan individu (B) serangga fitofag. Huruf yang sama pada gambar yang sama menunjukkan tidak berbeda nyata menurut uji Duncan pada taraf kepercayaan 95\%

Heracleum spp. genotipe asli dan genotipe invasif memiliki komposisi serangga herbivora yang sama. Hal tersebut berlawanan dengan hasil penelitian Cappuccino dan Carpenter (2005) bahwa tanaman pendatang yang dikategorikan menjadi invasif memiliki kekayaan spesies serangga fitofag yang lebih sedikit dari pada tanaman pendatang yang tidak dikategorikan menjadi invasif.

Berdasarkan Gambar 2, pola ordinasi MDS serangga fitofag ini dinilai layak, dan hal ini terlihat dari hasil stress yang didapatkan $<0,2$. Jika nilai stress

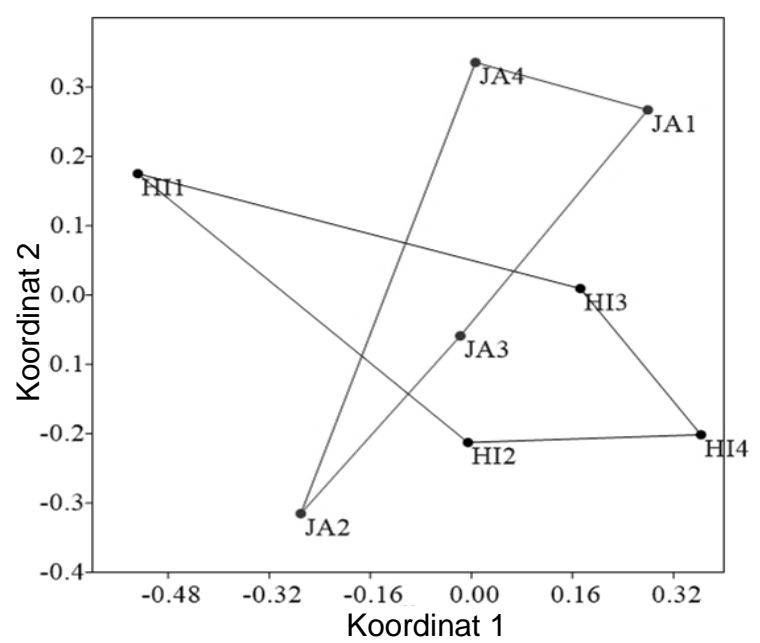

Gambar 2 Ordinasi MDS serangga fitofag pada sengon Jawa (JA) dan sengon Hawaii $(\mathrm{HI})$ (stress value: 0,024). Angka 1 sampai 4 menunjukkan blok yang didapatkan >0,2 maka dapat dikatakan bahwa model ordinasi yang didapatkan tidak dapat dipergunakan (Clarke 1993). Nilai ANOSIM berdasarkan indeks kesamaan Bray-Curtis dari serangga fitofag kedua sengon tersebut ditunjukkan pada nilai $\mathrm{R}=0,24$ dan $p$ value $=0,06$. Hal tersebut membuktikan bahwa komposisi serangga fitofag pada sengon dari Jawa dan Hawaii tidak menunjukkan perbedaan.

Pada hasil ordinasi MDS tampak bahwa semakin dekat jarak antartitik menunjukkan kemiripan komposisi spesies. Distribusi titik MDS serangga fitofag pada masing-masing blok sengon Jawa menunjukkan kemiripan komposisi serangga fitofag pada sengon dari Jawa dan Hawaii. Berdasarkan titik ordinasi masing-masing blok menunjukkan bahwa kemiripan komposisi serangga fitofag relatif dekat pada tanaman sengon Jawa blok 3 (JA3), sengon Hawaii blok 2 (HI2), dan sengon Hawaii blok 3 (HI3). Kemiripan ketiga blok tersebut relatif lebih mirip dibandingkan dengan komposisi serangga fitofag pada sengon di blok yang lain.

\section{Hama Penting pada Tanaman Sengon}

Terdapat 10 spesies yang memiliki urutan tertinggi dalam penyusunan komposisi serangga (Tabel 2). Spesies-spesies tersebut adalah Eurema blanda (Lepidoptera: Pieridae) yang merupakan spesies yang memiliki kontribusi terbesar $(58,60 \%)$ dibandingkan spesies yang lain. Selain E. blanda, terdapat 9 spesies serangga fitofag lain yang memiliki nilai kontribusi yang relatif besar. Serangga tersebut adalah Schistocerca 
Tabel 2 Hasil uji Simper pada serangga fitofag pada tanaman sengon

\begin{tabular}{ccc}
\hline Spesies serangga fitofag $^{1}$ & Kontribusi (\%) & Stadia \\
\hline Eurema blanda & 58,6 & Larva \\
Schistocerca pallens & 8,4 & Imago \\
Eurema hecabe & 3,9 & Larva \\
Pteroma plagiophleps & 2,8 & Larva \\
Ferrisia virgata & 2,1 & Imago \\
Leptocorisa acuta & 1,9 & Imago \\
Hulodes caranea & 1,7 & Larva \\
Margarodes sp. & 1,6 & Imago \\
Choristoneura sp. & 1,4 & Larva \\
Adoxophyes sp. & 1,4 & Larva \\
\hline 1) Ditampilkan 10 spesies dengan urutan kontribusi paling \\
tinggi
\end{tabular}

pallens (Orthoptera: Acrididae), E. hecabe (Lepidoptera: Pieridae), Pteroma plagiophleps (Lepidoptera: Psychidae), Ferrisia virgata (Hemiptera: Pseudococcidae), Leptocorisa acuta (Hemiptera: Alydidae), Hulodes caranea (Lepidoptera: Noctuidae), Margarodes sp. (Hemiptera: Margarodidae), Choristoneura sp. (Lepidoptera: Tortricidae), dan Adoxophyes sp. (Lepidoptera: Tortricidae).

Beberapa hama di atas telah dilaporkan oleh Surachman et al. (2014) dan Setyawan et al. (2018) seperti E. blanda, E. hecabe, dan P. plagiophleps yang merupakan serangga hama yang dapat menyebabkan defoliasi pada sengon, bahkan dapat menyebabkan kematian tanaman, terutama tanaman di bawah umur 2 tahun. Kutu putih $F$. virgata dan $S$. pallens juga dilaporkan menyerang tanaman sengon (Suharti 2002; Aprilia 2011). Kutu putih $F$. virgata banyak dijumpai pada tanaman di stadia pembibitan, dan kutu ini secara berkelompok akan menghisap cairan tanaman, terutama pada jaringan yang masih muda, seperti daun muda dan titik tumbuh. Belalang S. pallens merupakan jenis belalang generalis yang banyak dijumpai pada tanaman hortikultura, dan kemunculan belalang ini meningkat pada saat musim kemarau (Nair 2000; Tuhumury 2007). Sementara untuk $H$. caranea, Margarodes sp., Choristoneura sp., serta Adoxophyes sp. merupakan jenis serangga yang belum dilaporkan sebagai hama penting sengon.

Berdasarkan hasil pengamatan, larva E. blanda adalah hama penting yang paling mendominasi pada tanaman sengon. Larva ini merupakan jenis hama yang memiliki kelimpahan individu tertinggi dibandingkan dengan spesies serangga fitofag yang lain. Imago $E$. blanda berwarna kuning dengan karakter 3 titik hitam pada bagian ventral sayap depan. Larva $E$. blanda menjadi hama yang menjadi ancaman besar untuk tanaman sengon karena menyerang daun muda dan bahkan daun tua hingga menyisakan tulang daun yang kemudian dapat mengakibatkan tanaman kehilangan daun yang dapat mengganggu pertumbuhan hingga akhirnya dapat mengakibatkan kematian.

Populasi E. blanda tercatat menyerang tanaman sengon sejak $18 \mathrm{MST}$. Populasi larva E. blanda cenderung mengalami peningkatan seiring dengan pertambahan umur tanaman sengon (Gambar 3). Hal tersebut disebabkan karena imago $E$. blanda meletak- kan telurnya secara berkelompok pada permukaan daun sengon dengan jumlah mencapai 300 butir telur per daun. Hal ini didukung dengan laporan Tuhumury (2007) dan Aprilia (2011) yang menyebutkan bahwa larva $E$. blanda hidup berkelompok dan makan pada tanaman sengon. Faktor lain yang menyebabkan dominansi $E$. blanda adalah fase perkembangan yang relatif singkat. Fase telur 3 sampai 4 hari, larva 17 hari, pupa 5 sampai 6 hari, imago 10 hari, dan siklus hidup serangga tersebut hanya sekitar 36 hari (Nair 2007).

Peningkatan dan penurunan populasi suatu spesies tidak hanya dipengaruhi oleh faktor bottom-up (ketersediaan sumber daya inang), tetapi juga melibatkan top-down (musuh alami), perilaku serangga, kondisi iklim, serta interaksi dari berbagai faktor lainnya (Hamback et al. 2007; Thomas \& Reid 2007). Penurunan populasi $E$. blanda pada waktu pengamatan 26 dan 28 MST terjadi akibat banyaknya larva yang mati akibat parasitoid. Berdasarkan hasil pengamatan didapatkan Apanteles sp. (Hymenoptera: Braconidae) dari larva $E$. Blanda, dan Brachymeria sp. (Hymenoptera: Chalcididae) dari kepompong E. blanda. Populasi larva E. blanda kembali meningkat pada pengamatan 28 dan 30 MST. Salah satu faktor yang menyebabkan peningkatan populasi $E$. blanda adalah musim penghujan. Hal ini sesuai dengan hasil penelitian Irianto et al. (1997) yang melaporkan populasi $E$. blanda akan terus meningkat pada musim penghujan dan bahkan bisa terjadi ledakan populasi.

\section{KESIMPULAN}

Serangga fitofag yang diidentifikasi berasosiasi dengan persemaian sengon yang berumur 14 sampai 32 MST sebanyak 67 spesies. Pada sengon dari Jawa didapatkan 57 spesies, sedangkan pada sengon dari Hawaii didapatkan 54 spesies. Tidak terdapat perbedaan keanekaragaman dan kelimpahan serangga fitofag pada kedua asal sengon. Serangga fitofag yang menjadi hama paling dominan adalah larva $E$. blanda yang mengakibatkan defoliasi. Lebih lanjut lagi, beberapa hama yang memiliki kontribusi besar dalam

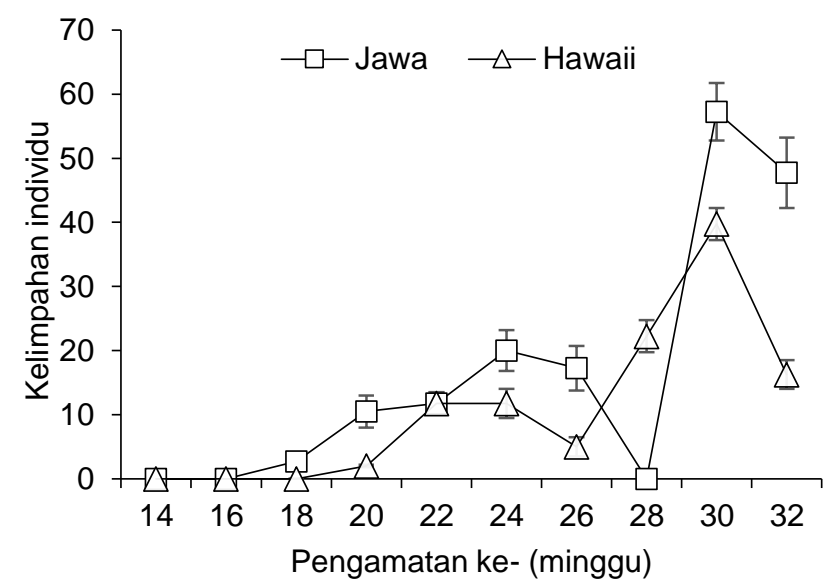

Gambar 3 Populasi larva Eurema blanda (rata-rata \pm SD) pada setiap pengamatan 
menyusun komposisi spesies dan belum dilaporkan sebagai hama pada sengon adalah $H$. caranea, Margarodes sp., Choristoneura sp., serta Adoxophyes sp. Hama-hama tersebut tergolong hama pemakan daun yang dapat mengakibatkan kerusakan hingga defoliasi pada sengon.

\section{UCAPAN TERIMA KASIH}

Ucapan terima kasih disampaikan kepada Forest Service - United States Department of Agriculture (USDA) atas pendanaan dalam penelitian ini. Penelitian ini merupakan bagian dari program Albizia Biological Control. Terima kasih juga disampaikan kepada Bapak dan lbu pendamping di Laboratorium Biosistematika Serangga dan rumah kaca. Terima kasih kepada lbu Lia Nurulalia, Bapak Herry Marta Saputa, Muhammad Lutfi, dan Fitrah Murgianto dalam bantuannya selama penelitian baik di lapangan maupun di laboratorium.

\section{DAFTAR PUSTAKA}

Aprilia NT. 2011. Studi pustaka hama sengon (Paraserianthes falcataria (L) Nielsen). [Skripsi]. Bogor (ID): Institut Pertanian Bogor.

[BIISC] Big Island Invasive Species Committee. 2015. Albizia in East Hawaii Roadside Hazards. Hawaii (US): Manoa Bc.

Blossey B, Notzold R. 1995. Evolution of increased competitive ability in invasive nonindigenous plants: a hypothesis. Journal of Ecology. 83(5): 887-889. https://doi.org/10.2307/2261425

Blumenthal D. 2005. Interrelated causes of plant invasion. Science. 310: 243-246.

Budiawan, Arifin H, Suprayogi K. 2012. Manual Pelatihan-Pelatihan Teknik Persemaian dan Silvikultur Volume 3. Jakarta (ID): Kemenhut RI.

Bürki CB, Nentwig W. 1997. Comparison of herbivore insect communities of Heracleum sphondylium and H. mantegazzianum in Switzerland (Spermatophyta: Apiaceae). Entomologia Generalis. 22: 147-155.

Cappuccino N, Carpenter D. 2005. Invasive exotic plants suffer less herbivory than non-invasive exotic plants. Biology Letters. 1(4): 435-438. https://doi. org/10.1098/rsbl.2005.0341

Chandler MA, Skinner LC, Riper LCV. 2016. Biological Control of Invasive Plants in Minnesota. [Internet]. [diunduh pada 2016 Des 23] tersedia pada: www.dnr.state.mn.us/eco/invasives/index.html
Clarke K. 1993. Non-parametric multivariate analyses of change in community structure. Australian Journal of Ecology. 18: 117-143.

Frenzel M, Brandl R. 2003. Diversity and abundance patterns of phytophagous insect communities on alien and native host plants in the Brassicaceae. Ecography. 26: 723-730.

Gilligan TM, Passoa SC. 2014. Leplntercept - An identification resource for intercepted Lepidoptera larvae. [internet]. [diunduh pada 2016 Okt 14] tersedia pada: htpp://idtools.org/id/leps/lepintercept/lucidkey.html.

Haines WP, Barton KE, Conant P. 2011. Defoliation of the invasive tree Falcataria moluccana on Hawaii Island by the native koa looper moth (Geometridae: Scotorythra paludicola), and evaluation of five Fabaceous trees as larval host plants. Hawaiian Entomological Society. 45: 129-139.

Hamback P, Vogt M, Tscharntke T, Thies C, Englund G. 2007. Top-down and bottom-up effects on the spatiotemporal dynamics of cereal aphids: testing scaling theory for local density. Oikos. 116: 1995-2006.

Hughes RF, Johnson MT, Uowolo A. 2013. The invasive alien tree Falcataria moluccana. Di dalam: Dennill G, Donnelly D dan Stewart K, editor. Prospects for Weed Biological Control in Pacific Islands XIII. Institute of Pacific Islands Forestry, Hawaii (US): USDA Forest Service. hlm 218-223.

Irianto RSB, Matsumoto K, Mulyadi K. 1997. The yellow butterfly species of the genus Eurema hubner causing severe defoliation in the forestry plantations of Paraserianthes falcataria (L) Nielsen, in the western part of Indonesia. Japan International Research Center for Agricultural Science. 4(4): 41-49.

Joshi J, Vrieling K. 2005. The enemy release and EICA hypothesis revisited: incorporating the fundamental difference between specialist and generalist herbivores. Ecology Letters. 8(7): 704-714. https:// doi.org/10.1111/j.1461-0248.2005.00769.x

Kleunen M, Weber E, Fischer M. 2010. A meta-analysis of trait differences between invasive and noninvasive plant species. Ecology Letters. 13(2): 235-245. https://doi.org/10.1111/j.1461-0248.200 9.01418.x

Kolar CS, Lodge DM. 2001. Progress in invasion biology: predicting invaders. Trends in Ecology \& Evolution. 16(4): 199-204. https://doi.org/10.1016/ S0169-5347(01)02101-2

Krisnawati H, Varis E, Kallio M, Kanninen M. 2011. Paraserianthes falcataria (L.) Nielsen Ekologi, Silvikultur dan Produktivitas. Bogor (ID): CIFOR. 
Lieurance D. 2012. Mechanisms of success: plantherbivore interactions and the invasion of nonnative Lonicera species in North America. [Disertasi]. Ohio (US): Wright State University.

Liu H, Stiling P, Pemberton RW, Pe, xf, a J. 2006. Insect Herbivore Faunal Diversity among Invasive, Non-Invasive and Native Eugenia Species: Implications for the Enemy Release Hypothesis. Florida Entomologist. 89(4): 475-484. https://doi.or g/10.1653/0015-4040(2006)89[475:IHFDAI]2.0.CO ;2

Murdiyarso D, Wahid P, Adelia R. 1992. Status air tanaman sengon (Albizia falcataria (L.) Fosberg) tempat tumbuh. Jurnal Agromet. 8(1): 41-53.

Nair KSS. 2000. Insect Pests and Diseases in Indonesian Forests. Bogor (ID): Central of International Forestry Research.

Nair KSS. 2007. Tropical Forest Insect Pests. New York (US): Cambridge University Press.

Nusantara AD. 2002. Tanggap semai sengon [Paraserianthes falcataria (L) Nielsen] terhadap inokulasi ganda cendawan mikoriza Arbuskular dan Rhizobium sp. Jurnal IImu Pertanian Indonesia. 4(2): $62-70$.

Richardson DM, Pysek P, Barbour MG, Panetta FD, Rejmánek M, West CJ. 2000. Naturalization and invasion of alien plants: concepts and definition. Diversity and Distributions. 6: 93-107.

Rizali A, Tscharntke T, Buchori D, Clough Y. 2017. Separating effects of species identity and species richness on predation, pathogen dissemination and resistance to invasive species in tropical ant communities. Agricultural and Forest Entomology. 20(1): 122-130. https://doi.org/10.1111/afe.12236

Setyawan YP, Hidayat P, Puliafico KP. 2018. Herbivorous insects associated with albizia (Falcataria moluccana) saplings in Bogor. IOP Conference Series: Earth and Environmental Science. 197(1).

Siregar UJ, Rachmi A, Massijaya MY, Ishibashi N, Ando K. 2007. Economic analysis of sengon (Paraserianthes falcataria) community forest plantation, a fast growing species in East Java, Indonesia. Forest Policy and Economics. 9(7): 822-829. https://doi.org/10.1016/j.forpol.2006.03.0 14

Soeparno, Dwiyono A. 2013. Modul pelatihan persemaian. Bandung (ID): Citarum Watershed Management and Biodiversity Conservation.

Speight M, Hunter M, Watt A. 1999. Ecology of insects: concepts and applications. Oxford (GB): Blackwell Scientific.

Stam JM, Kroes A, Li Y, Gols R, van Loon JJ, Poelman $\mathrm{EH}$, Dicke M. 2014. Plant interactions with multiple insect herbivores: from community to genes. Annual Review of Plant Biology. 65: 689-713.

Starr F, Starr K, Loope L. 2003. Falcataria moluccana (Molucca albizia). Hawaii (US): United States Geological Survey-Biological Resources Division.

Stehr FW. 1987. Immature Insect. lowa (US): KendallHunt Publishing.

Stork Ne. 1988. Insect diversity: facts, fiction and speculation. Biological Journal of the Linnean Society. 35: 321-337.

Suharti M. 2002. Beberapa hama dan penyakit penting pada sengon (Paraserianthes falcataria) dan teknik pengendaliannya. Buletin Penelitian Hasil Hutan. 632: $27-46$.

Surachman IF, Indriyanto, Hariri AM. 2014. Inventarisasi hama persemaian di hutan tanaman rakyat Desa Ngambur Kecamatan Bengkunat Belimbing Kabupaten Lampung Barat. Jurnal Sylva Lestari. 2(2): 7-16. https://doi.org/10.23960/jsl227 16

Thomas MB, Reid AM. 2007. Are exotic natural enemies an effective way of controlling invasive plants? Trends in Ecology \& Evolution. 22(9): 447-53.

Tscharntke T, Karp DS, Chaplin-Kramer R, Batary P, DeClerck F, Gratton C, Hunt L, Ives A, Jonsson M, Larsen A, Martin EA, Martínez-Salinas A, Meehan TD, O'Rourke M, Poveda K, Rosenheim JA, Rusch A, Schellhorn N, Wange TC, Wratten S, Zhang W. 2016. When natural habitat fails to enhance biological pest control - Five hypotheses. Biological Conservation. 204: 449-458. https://doi.org/10.10 16/j.biocon.2016.10.001

Tuhumury A. 2007. Inventarisasi jenis hama pada tanaman sengon (Paraserianthes falcataria Nielson) di lokasi hutan kemasyarakatan Waesamu, Kecamatan Kairatu Kabupaten Seram Bagian Barat. Jurnal Agroforestri Indonesia. 2(1): 14-18.

Vila M, Espinar J, Hejda M, Hulme P, Jarosik V, Maron J. 2011. Ecological impacts of invasive plants: a meta-analysis of their effects on species, communities and ecosystems. Ecology Letters. 14(1): 702-708. https://doi.org/10.1111/j.14610248 .2011.01628.x

White EM, Sims NM, Clarke AR. 2008. Test of the enemy release hypothesis: the native magpie moth prefers a native fireweed (Senecio pinnatifolius) to its introduced congener ( $S$. madagascariensis). Austral Ecology. 33(1): 110-116. https://doi.org/10 .1111/j.1442-9993.2007.01795.x

Wikstrom SA, Steinarsdottir MB, Kautsky L, Pavia H. 2006. Increased chemical resistance explains low herbivore colonization of introduced seaweed. Oecologia. 148(4): 593-601. 
Wong BJ. 2012. Effects of an invasive tree species (Falcataria moluccana) on understory diversity in Mo'orea, French Polynesia. Pacific Science. 34(3): 367-379.

Zou J, Rogers WE, Siemann E. 2008a. Increased competitive ability and herbivory tolerance in the invasive plant Sapium sebiferum. Biological Invasions. 10(3): 291-302.

Zou J, Siemann E, Rogers WE, Dewalt SJ. 2008b. Decreased resistance and increased tolerance to native herbivores of the invasive plant Sapium sebiferum. Ecography. 31(5): 663-671. 